\title{
RECENT PHASES OF CHICAGO'S TRANSPORTATION PROBLEM
}

\author{
By Willard E. Hotchkiss, Ph.D., \\ Northwestern University, Evanston, Ill.
}

At the time the author's previous article ${ }^{1}$ on Chicago traction went to press, the situation seemed about to emerge from the state of perpetual chaos which had characterized it during the preceding two decades. To summarize briefly, the Yerkes domination in the north and west sides, dating from the late eighties, was contemporaneous with the lowest degradation of the city's political life. The signs of political revolt witnessed in the partial regeneration of the city council after the organization of the Municipal Voters' League in 1896 had been followed by an attempt to jam through the state legislature a fifty-year extension of franchises, many of which, under a compromise agreement of 1883 , were to expire in 1903 . The law that finally passed after public indignation had forced the legislature to modify its action, merely empowered the city council to extend franchises for that period. After many of its supporters had lost their seats in the political upheaval which followed, it was repealed by the next legislature without ever having been acted on by the city council.

Since their failure at Springfield in 1897 the companies have been largely on the defensive and have been face to face with a hostile public sentiment extending throughout the state. Their rights after the expiration of specific grants depended upon the socalled Ninety-nine Year Act, an ambiguous measure which it was claimed extended the franchises of the three original companies for ninety-nine years from 1865 , the date of its passage. The denial of this claim by the United States Supreme Court in I906 was in large measure responsible for the willingness of the companies to negotiate on a basis more favorable to the city than any which had previously been proposed.

The physical and financial aspects of the situation during the last decade have appeared, if possible, in even worse light than the

IANAaLs, Vol. XXVIII, November, 1006.

(6I9) 
political. The systems under Mr. Yerkes' control were knit together with a maze of community interests, leases, operating agreements, sales and other legal entanglements, and in the process were loaded with a weight of liabilities out of all proportion to investment. The retirement of Yerkes when the Union Traction Company was organized in 1899 , and the subsequent bankruptcy of that company made "confusion worse confounded." Every attempt to compel unified operation of the companies under Yerkes, and later under Union Traction control, was steadfastly resisted, so far as service and issue of transfers were concerned. While the various financial and legal exploits were being consummated, deterioration of physical properties and neglect in other ways made the service from every point of view absolutely intolerable.

All of these facts are essential to an understanding of the municipal ownership sentiment which has shown itself so forcibly during the last decade and which now, when a settlement seems to be assured, has momentarily at least, in large measure subsided. The strong municipal ownership majorities of 1902, 1904, I905 and I906, as well as the tremendous popular agitation which forced a reluctant legislature to pass the Müller $\mathrm{Law}^{2}$ in 1903 , represented, in addition to the real municipal ownership sentiment, a protest against existing conditions. The Müller Law numbered among its stanchest supporters a large number of men who were theoretically opposed to municipal ownership, but who believed that without the weapon which the legal and financial power to municipalize would give, the city could never hope to make a satisfactory arrangement with private companies.

These men were not found among the supporters of Mayor Dunne and his immediate municipal ownership program in 1905. His election in spite of the opposition both of those who believed in municipal ownership as an ultimate goal, and those who regarded the Müller Law simply as a club, was naturally interpreted as a mandate to accomplish municipal ownership and operation at the earliest possible moment. After a year of friction between the mayor and the council, an ordinance was passed early in 1906, which provided for the issue of seventy-five million dollars of street railway-certificates, to be a charge merely on the street railway prop-

\footnotetext{
This law aimed to give the city the legal and financial power to accomplish municipal ownership. For its exact provisions see Axsals, November, 1906, page 394.
} 
erties and not on the general credit of the city. Such certificates had been authorized by the Müller Law in order that municipal ownership might be accomplished without infringing upon the city's constitutional and statutory debt limit.

The seventy-five million dollar certificate ordinance was approved at the spring election of 1906 , but before that time the improvement in the city's position through the overthrow of the Ninety-nine Year Act had led to the reopening of negotiations with the existing companies. By September of that year the principles of settlement involving the mayor's proposals were accepted by the companies. It was agreed that the new ordinances should contain the following provisions:

I. Sale to the city of all tangible property and unexpired rights at a price to be fixed in advance.

2. Continued operation by the companies under revokable license.

3. Reconstruction of the entire system upon plans adopted by the city with concurrence of the companies.

4. Improved service to provide for: (a) unification of all routes; $(b)$ through routes; $(c)$ universal transfers.

5. Adequate assurance to the companies of the ultimate payment for present values of properties, and for additional investments, whenever the city should take over the lines.

6. Fair return upon present and future investments, with some share of net profits.

7. Remaining profits to go to the city as a sinking-fund for the purchase of properties.

The companies had at that time placed a total valuation upon their properties of over seventy-three million dollars, distributed as follows: The Union Traction Company, tangible property, \$29,294,292 ; intangible, $\$ 13,825,040$. The City Railway Company, tangible property, $\$ 20,103,936$; intangible, $\$ 10,322,228$. These valuations were considered much too large, and a board of expert engineers, consisting of Mr. Bion J. Arnold, Mr. L. E. Cooley and Mr. A. B. duPont, were commissioned by the city to evaluate the properties. The result of their evaluation was to diminish the companies' estimate to $\$ 46,652,747$, exclusive of charges for paving, which, if included, would have brought the estimate up to $\$ 50,994,782$, as against $\$ 73,555,675$ demanded by the companies. 
Negotiations were carried on for several months between representatives of the companies and the mayor and city council committee on local transportation, represented by special traction attorney, Mr. Walter Fisher. The question of compensation was finally solved by both parties agreeing to a valuation of fifty million dollars for all properties and rights, tangible and intangible. It will be noticed that this agreement conceded to the companies a very large part of their paving claims. The ordinance drawn up and agreed to by Mr. Fisher and the companies embodied practically all the provisions referred to above. It also contained minute specifications concerning rehabilitation, the establishment of through routes, character of service, financial operations, and placed the execution of the provisions largely in the board of consulting engineers. Several of the details, however, were felt by many, especially by the advocates of municipal ownership, to place very serious obstacles in the way of municipa'ization. Provision had been made only for the issue of seventy-five million dollars in Müller Law certificates, and it is estimated that, at the lowest, rehabilitation of existing lines would cost forty million dollars, bringing the amount necessary to finance a municipalization project up to ninety million dollars.

It had been suggested that in the event of failure to finance a plan of municipal ownership by means of the Müller Law certificates, the same result could be accomplished by organizing a company, pro bono publico, to take over the lines under the so-called contract plan. Such a plan was considered the more seriously because the supreme court of the state had not yet passed upon the constitutionality of the certificates feature of the Müller Law. In view of this situation, it is not surprising that the advocates of municipal ownership viewed with some misgivings the provisions of the ordinance which decreed that, in the event of municipalization, the city should pay to the companies in cash the full amount of the present valuation, plus any sums expended in rehabilitation of the lines, plus ten per cent contractors' profit, and five per cent brokerage over the actual cost of construction. For the contingency, moreover, of the properties being purchased, not by the city, but by another corporation, provision is made for the addition of twenty per cent to the price calculated as above. The additional twenty per cent is not to be charged, however, in case the prospective purchaser enters into a binding contract with the city which 
limits his beneficial interest in the properties to money actually invested, plus a five per cent profit and interest on the total sum. It is obvious that the provisions here outlined, especially in view of the city's financial situation, cannot fail to have a very important bearing upon the problem of municipal ownership. The action of the supreme court of the state on April 18, 1907, declaring the certicate feature of the Müller Law invalid, will make municipalization impracticable, if not impossible, for a considerable time to come.

The second point of contention between the city and the companies had to do with division of profits. The plan finally agreed upon provided that fifty-five per cent of net profits should go to the city and forty-five per cent to the companies. Obviously a provision of this kind depends for its value, so far as the city is concerned, upon the good faith with which it is carried out. Chicago has had ample demonstration of the way in which net profits may be consumed even by the most prosperous transportation companies. It was freely predicted by the opponents of the ordinances that no such profits would accrue. The provision upon which those who favored the ordinances relied for the security of the city's share of net profits was the feature creating a board of supervising engineers. $^{3}$ This board consists of three engineers, one appointed by the city, one by the companies, the third to be Mr. Bion J. Arnold, who is chairman of the board. It will be seen that the city practically appoints two members of the original board against the companies' one. With Mr. Arnold in charge, great confidence is felt for the security of the city's interests. Should a vacancy occur in the chairmanship of the board by Mr. Arnold's death, incapacity or resignation, specific provision is made for the selection of a chairman. ${ }^{4}$

Ordinances embodying these provisions were drawn up in favor of the Chicago City Railway Company for the lines on the south side, and the Chicago Railways Company for the lines under

\footnotetext{
rThe board of engineers is given full power to control all expenditures for rehabilitation as well as complete supervision over the operation of the lines. The letting of contracts, the purchase of supples, the sale of unnecessary property, and even the regulation of salaries is brought under its supervision and control.

${ }^{+}$In case of the fallure of the city and the companies to agree upon a person to fill the position of third engineer and chalrman within thirty days after the vacancy occurs, the judges of the appellate court for the first district of Illinois may, upon application of either party, ten days' notice having been given the other party, fill the vacancy. The judges may also, at their discretion, remove the chairman after due notice and public hearing, upon the request of either party.
} 
the control of the Union Traction Company on the north and west sides. Provision was made, moreover, that in the event of the Chicago Railways Company being prevented by legal obstacles from accepting its ordinance, the Chicago City Railway Company should acquire street privileges similar to those held on the south side in all of those streets in which the rights of the Union Traction Company or of its various subsidiary companies had expired.

After substantial agreement had been reached between the mayor's counsel and the representatives of the companies, the advocates of municipal ownership, including Mayor Dunne, repudiated Mr. Fisher's work and came out for immediate municipal ownership, to be secured by condemnation proceedings. This was practically the position of the Democratic party with Mayor Dunne as its candidate for re-election in the municipal campaign preceding the election of April 7, 1907. The result of opposition on the part of municipal ownership advocates was a demand for a referendum, which was at first unwisely opposed by some of the leaders of the movement for approval of the ordinances. The sentiment in favor of the referendum upon all important measures is so well established in Chicago, due in part to the experience of the people precisely upon matters connected with transportation, that no wise political leader can afford to run counter to it. It soon became obvious that the demand could not be safely resisted; one hundred and eighty-nine thousand signatures were secured for a referendum petition. The ordinances, with minor amendments, were accordingly passed on February 5, 1907, to become operative when approved by popular vote. They were vetoed by Mayor Dunne and promptly passed over his veto at the next session of the council.

The action of the city council in passing the ordinances has been the subject of much discussion. Several amendments were offered for the purpose of further safeguarding the city, but inasmuch as the special traction counsel, Mr. Fisher, declared that everything had been secured which it was possible to persuade the companies to accept, there seems to be little doubt that the majority of the council were entirely sincere in preferring to waive these safeguards rather than cause defeat of the ordinances, since defeat, it was felt, would again plunge the traction problem into chaos. As to the division of the council, the men who have usually been classed among the ablest members largely supported the measures; 
they were also supported by the remnant of the "gray wolf" element. Those who opposed them were for the most part men who have a record for honesty in the council. So far as the author is aware, there have been no serious charges of improper motives on either side.

The Republican party, after the ordinances were passed, came out squarely in favor of them and nominated for mayor Postmaster Busse, a machine politician of remarkable force and indifferent reputation for civic virtues. Party lines, however, were not closely drawn in the campaign. Many elements in the Democratic party were hostile to Mayor Dunne as well as to his position in repudiating the ordinances which his special counsel had drawn up. A considerable number of Republicans who favored the ordinances either repudiated the candidate for mayor or supported him reluctantly as a doubtful alternative against the incompetence of the Dunne régime. The ordinances carried by a vote of 165,846 to I32,720, while Mr. Busse's majority over Mayor Dunne was only about I3,000.

With the approval of the ordinances and the action of the supreme court in setting aside the certificate feature of the Müller Law, it only remained to disentangle the legal difficulties of the north and west side lines. The companies were given until July first to accept their ordinances. The City Railway Company promptly accepted its measure, but some of the bondholders of the north and west side companies declined to accept the reduced valuation occasioned by the overthrow of the Ninety-nine Year Act; this action threw the whole question of giving the Chicago Railways Company possession of the north and west side lines into the courts. It will be remembered that the result of Yerkes' domination in the north and west sides, and of the various manipulations incident to the transfer of control over these interests to the Union Traction Company, was a series of operating agreements, leases, community interests, and nearly all of the other devices known to corporation law. The value of the properties turned over under this series of legal mysteries was in many cases either fictitious or entirely unascertainable. The relation existing between the subsidiary companies, moreover, had become so absolutely entangled that there was no possibility of determining either the legal rights or equities of the various stockholders, bondholders, leaseholders and other 
claimants of the several companies. The bankruptcy of the Union Traction Company and its operation by a receiver had not clarified the legal situation.

It soon became obvious that no agreement would be possible in time to accept the ordinance on July first. Accordingly, an extension was granted to September fifteenth; meanwhile United States Circuit Judge Grosscup, under the jurisdiction of whose court the Union Traction receivership had been operated, together with Professor John C. Gray, of Harvard University, worked out a plan of compromise calculated to protect the equities of the various claimants. On July fifteenth the Chicago Railway Company petitioned the court to have the properties delivered to them under the plan thus formulated, and by decree of Judge Grosscup, issued August I2, 1907, the properties were ordered to be so leased. It was acknowledged that the new obligations created for the moneys to be expended under the ordinances would displace certain vested liens. On the other hand, since without the ordinances the rights in question would be practically valueless, the court was confronted by a situation in which, in the language of the judge, it was "unthinkable that a court of chancery is powerless to accept life, but has power only to accept a sentence of death, which a failure to accept the ordinances would practically mean."

On appeal to the circuit court of appeals, the order of Judge Grosscup was set aside by a decree of Justice Brewer, delivered September 7, 1907. This again threw the whole situation into uncertainty and made necessary a further request for extension of time, which was granted by the city council, with the warning that unless the Chicago Railways Company were in a position to accept the ordinances by February I, 1908, their rights in the premises would at that time cease and determine and the ordinance would pass to the Chicago City Railway Company. Negotiations were again begun between the various interests, and finally an agreement was reached under which a decree of foreclosure and sale was issued by Judge Grosscup on December 26, I907. On January 25, 1908, the various properties of the north and west side were sold at public auction to the Chicago Railways Company for an aggregate sum slightly exceeding two million dollars. On January thirty-first the decree confirming sale was issued just in time to permit the acceptance of the ordinance under the second extension. Since 
that time various rumors of a merger between the two companies have been heard, but as yet nothing of the sort seems to have been accomplished.

The legal tangles have naturally furnished an excuse for delay in the realization of improvement in service, especially in those portions of the city where improvement is most needed. Some of the through routes provided for in the ordinance have already been established, but for the most part, with the exception of a few new cars, and some improvement of the roadbed in certain sections, the city is enjoying so far essentially the same transportation facilities that it had two years ago. It is entirely too early to pass final judgment upon the outcome of the present arrangement under which the city becomes practically the partner of the companies in the operation and extension of its transportation system. Even under the most favorable circumstances, several years will be consumed in the rehabilitation of lines and the provision of adequate rolling stock. In the meantime, with the growth of the city, the transportation problem is becoming constantly more acute, and by the time the construction of subways is undertaken, the need for enlarged facilities will unquestionably be just as urgent as is the need for improvement of surface lines at the present time.

There are several features of the situation presented by the acceptance of the new ordinances regarding which it is perhaps even now possible to pass judgment. The experience of the first eleven months operation under the new ordinance of the Chicago City Railway Company would seem to indicate that the city may fairly expect considerable revenue under the present arrangement. ${ }^{5}$ It seems probable that the powers lodged with the board of supervising engineers are adequate to protect the city's interests in this regard, at least so long as the board is constituted as at present.

Several interesting questions have arisen concerning the status of the problem under the present ordinances. The spring campaign of 1907 brought to light a variety of divergent views upon this question. It was emphatically asserted by the framers of the ordinances that the city was not granting a franchise, but a license revokable at will. Those who opposed the ordinances as well as those who believed that, with all their shortcomings, they consti-

"Information which became available after the above was written shows the clty's share of net receipts of both companies during the first year of operation under the new ordinances to have been nearly one and one-half million dollars. 
tuted the best arrangement feasible under the circumstances, were of the opinion, on the other hand, that in their practical operation they would prove to be twenty-year franchises, and franchises to which more or less onerous conditions as to purchase were unfortunately attached. In this connection it is interesting to note that, in an advertisement of bonds of the City Railway Company sent out by the Harris Trust and Savings Bank on July I, I907, the company is spoken of as possessing a twenty-year franchise, and particular emphasis is laid, as would be expected, upon the provision for purchase only upon payment of cash for the present valuation. of the properties, plus improvements, with an increase of twenty per cent if purchased except for municipal operation.

Of course, over against the assumption, which now seems to be fairly general, that the companies are operating under a twentyyear franchise, the fact remains that should the abuses which have in the past prevented the establishment of adequate transportation facilities be continued, the city has, in the place of a maze of conflicting rights and claims, a perfectly definite contract which gives it an unquestioned legal right to purchase at any time upon six months' notice. If intolerable service continues, there seems little doubt that the cry of municipal ownership will be revived, in which case, sooner or later, some means of financing the enterprise would without doubt be devised, however advantageous and profitable to the companies might be the terms of sale. On the other hand, if the board of supervising engineers should prove to be an efficient regulating commission, there would seem to be no reason why a reputable transportation system should not soon be realized.

Whatever future action may be necessary to secure, under favorable conditions, a satisfactory transportation system, the ordinances under which the two Chicago companies are now operating mark an advanced step in the direction of safeguarding by definite and minute specifieation the interests of the public. Whether or not this method will ultimately characterize the most efficient form of public regulation, it is the author's opinion that the approval of the present ordinances, after careful discussion pro and con, first by experts, then by the city council and finally by the people, amply bears out the assumption that the history of the transportation problem in Chicago may rightly be considered a study in political evolution. 
Candid critics will probably all agree that the present ordinances contain a number of serious faults. It is to be expected, moreover, that experience under them will bring to light other faults not less serious. They are essentially compromises, not only between the city and the companies, but between the different shades of opinion upon the subject of municipal ownership. Not all provisions, desirable in temporary measures preparatory to municipal ownership would be equally applicable to twenty-year franchises. To cite a single illustration, agreement, forced or voluntary, upon a price for existing properties and rights was absolutely indispensable to the accomplishment of municipal ownership, either immediately or within the next two or three years. It is not clear, however, that after the companies have enjoyed ten or twenty years of profitable operation, the coming generation will regard with entire favor the obligation to pay in case of purchase an amount which constituted a liberal price for properties and rights in existence in 1907 .

In spite of their imperfections the ordinances under which the two Chicago companies are now operating mark an advance step in the direction of safeguarding, by definite and minute specifications, the interests of city and public. Whether this method alone will ultimately characterize the most efficient form of public regulation is perhaps doubtful. It is not improbable that in Chicago, as elsewhere, bodies charged with the execution of specific provisions, as is the board of consulting engineers, will need to be reinforced by a commission to which is delegated the broad regulative power of state or city. Whatever future action may be necessary to secure, under favorable conditions, a satisfactory transportation system, it is the author's opinion that approval of the present ordinances, after careful discussion pro and con, first by experts, then by the city council and finally by the people, when compared with methods of dealing with transportation matters in past years, amply bears out the assumption that the history of the transportation problem in Chicago may rightly be considered a study in political evolution. 